\title{
ECONOMIC ANALYSIS OF PRO PARTE DOLUS PRO PARTE CULPA FORMS OF GUILT IN PASSIVE MONEY LAUNDERING: A CRITICISM OF LAW NUMBER 8 OF 2010
}

\author{
Sanjaya Aditya Wiguna*, Doctoral Candidate \\ Nurjaya I Nyoman, Professor \\ Djatmika Prija, Associates Professor \\ Masruchin Ruba'i, Professor \\ Faculty of Law, University of Brawijaya, Malang, Indonesia \\ *E-mail: adityasanjaya962@gmail.com
}

\begin{abstract}
This article aims to analyze pro parte dolus pro parte culpa form of guilt in the passive money laundering formula as stipulated in article 5 paragraph (1) of Law Number 8 of 2010 from an economical approach to law. The method used in writing this article is a normative legal research method with a conceptual approach and a statute approach. The result of writing this article is that when viewed from the perspective of an economic approach, pro parte dolus pro parte culpa form of guilt in Article 5 paragraph (1) of Law Number 8 of 2010 which will result in passive money laundering, which is carried out due to negligence is also punishable by imprisonment spending the state budget only for minor offenses. In other words, it will just waste the state budget for disproportionate interests. With the existence of a large state budget expenditure, especially for the operationalization of the implementation of imprisonment against passive money laundering, which is carried out due to negligence, the government's efforts to increase state revenue, especially from the tax sector, and also efforts to recover state losses through law enforcement to money laundering will become a hopeless problem. The state budget allocated for this purpose should be used to achieve public welfare, for example, for health, education, and so on. In short, the existence of a large state budget expenditure, especially for the operationalization of the implementation of imprisonment against passive money laundering committed due to negligence, will reduce the state budget that should be used to fulfill the community's welfare.
\end{abstract}

\section{KEY WORDS}

Economic analysis, pro parte dolus pro parte culpa, forms of guilt, passive money laundering.

In the consideration considering letter b of Law Number 8 of 2010, it is stated that the prevention and eradication of the crime of money laundering requires a strong legal basis to ensure legal certainty, the effectiveness of law enforcement, and the tracing and return of assets resulting from criminal acts. The considerations considering letter b of Law Number 8 of 2010 are the background of the juridical aspects of the formation of Law Number 8 of 2010. Based on what is written in the considerations considering letter $b$ of Law Number 8 of 2010 , it can be seen that one of the goals to be achieved in the formation of Law Number 8 of 2010 is to follow the money or return the proceeds of crime.

This ideally applies to law enforcement against criminal acts that result in state financial losses. Looking at the considerations considering letter b of Law Number 8 of 2010 shows that the purpose of the formation of Law Number 8 of 2010 is to return the wealth that criminals have obtained by means that are illegal or against the law.

Meanwhile, what happened in Indonesia was that, in general, the practice of the law was still controlled by a legal regime that was oriented towards the perpetrator (follow the suspect), not on money orientation (follow the money) (Kristiana, 2015). Law enforcement efforts using money laundering instruments still clash with the old paradigm's walls (Kristiana, 2015). Strictly speaking, if law enforcement against the crime of money laundering is consistent with the background of the formation of Law Number 8 of 2010 as reflected in the considerations considering letter b of Law Number 8 of 2010, there should be a paradigm 
shift from follow the suspect to follow the money, or at least combine the follow the suspect paradigm and follow the money together.

Whereas in reality, law enforcement requires a very large amount of money, starting from the stage of investigation, investigation, prosecution, court examination to the implementation of court decisions, even including the cost of education or training of law enforcers, law enforcement facilities, and infrastructure, and so on (Nelson, 2020). In other words, the burden on the state in financing the criminal justice system from the entrance of the system to the entrance is already very heavy (Santoso, 2020).

When it is connected between the spirit of the birth of Law Number 8 of 2010 as stated in the considerations considering letter b of Law Number 8 of 2010 with the formulation of provisions for passive money laundering in Article 5 paragraph (1) of Law Number 8 of 2010 which is the wrong form of using pro parte dolus pro parte culpa, shows a contradictory logic. On the one hand the spirit of the birth of Law Number 8 of 2010 as contained in the considerations considering letter b of Law Number 8 of 2010 calls for tracing and returning assets resulting from criminal acts, but on the other hand the formulation of provisions for passive money laundering in Article 5 paragraph (1) Law Number 8 of 2010 has the potential to increase the burden on the state budget in terms of law enforcement, rather than seeking to trace and recover the results of criminal acts. Such arguments are based on the premise that the construction of Article 5 paragraph (1) of Law Number 8 of 2010 results in passive money launderers who commit a culpa to experience the same process as passive money launderers who do so on purpose (dolus).

The similarity of legal treatment for these two types of money laundering perpetrators starts from the pre-adjudication stage to the execution stage. A course in this series of processes will consume a significant amount of the state budget, as previously mentioned, even though if we consider other alternatives to passive money launderers who carry out their actions In the form of culpa, a mechanism that can save the state budget can be chosen by prioritizing efforts to follow the money in addition to following the suspect under the spirit of Law Number 8 of 2010.

In this regard, this article will analyze the formulation of the provisions for passive money laundering in Article 5 paragraph (1), which has pro parte dolus pro parte culpa form of guilt from an economic perspective approach to law.

\section{METHODS OF RESEARCH}

Doctrinal legal research with the statute and conceptual approaches was employed using secondary data consisting of primary legal materials in the form of statutory regulations, minutes of the formation of laws, academic texts, and secondary legal materials (all relevant legal publications and literature)

\section{RESULTS AND DISCUSSION}

The relation between the economic approach to the law and the follow the money paradigm in the anti-money laundering law. In Indonesia, money laundering is a category of crime in a new dimension that was not initially viewed as a despicable act. Therefore, it is not wrong if money laundering is called mala prohibita, it is not mala in se (Husak, 2008). In the Money Laundering Bill's academic text, the system and mechanism for law enforcement of money laundering or anti-money laundering regimes are different from conventional criminal law enforcement. Disclosure of criminal acts and perpetrators of money laundering focuses on tracing the flow of funds / illicit money (follow the money) or financial transactions (PPATK \& DPR RI, 2011).

The same substance is also mentioned in the general explanation of Law Number 8 of 2010 , namely in the concept of anti-money laundering, the perpetrators and the results of criminal acts can be identified through tracing, so that the results of these crimes are confiscated for the state or returned to those who have the right. Likewise, in consideration of letter b of Law Number 8 of 2010, it is stated that the prevention and eradication of the crime 
of money laundering requires a strong legal basis to ensure legal certainty, the effectiveness of law enforcement, as well as tracing and returning assets resulting from criminal acts. The last clause, "search and return of assets resulting from criminal acts" is a manifestation of the concept of following the money in Law Number 8 of 2010.

In principle, this shows a different and special character in the enforcement of the crime of money laundering. It can also be said to be a paradigm that differentiates law enforcement on the crime of money laundering and conventional criminal law enforcement. The difference lies in the case of law enforcement against the crime of money laundering. The paradigm adopted follows the money approach, while for conventional crime, the paradigm used is to follow the suspect approach (Kristiana, 2015).

Based on the experience of Indonesia and other countries, it shows that exposing criminal acts, finding the perpetrators, and placing the perpetrators in prison (follow the suspect) is not effective enough to reduce the crime rate if it is not accompanied by efforts to confiscate and seize the results and instruments of the act criminal. In this case, allowing the perpetrator of a criminal act to retain control over the results and instruments of a criminal act provides an opportunity for the perpetrator of the criminal act or other people who are related to the criminal offender to enjoy the proceeds of the crime and reuse the instrument of criminal activity or even develop criminal acts that have been committed (Yusuf, 2013).

According to Yudi Kristiana, the anti-money laundering legal regime seems to have departed from the punishment oriented towards "assets" or "follow the money". In this perspective, punishment is more asset-oriented, meaning it follows assets, which is why recovery of criminal assets, return of criminal assets for the benefit of the state and the injured party is one of the main objectives, as well as to break the chain of crime (Kristiana, 2015). This opinion is consistent with the intent of the legislators as reflected in the academic text of the Draft Law Number 8 of 2010, the considerations of consideration, and the general explanation of Law Number 8 of 2010.

In the anti-money laundering regime approach, the pursuit of money (follow the money) on the proceeds of crime is an easy and effective way to uncover crimes and their perpetrators, this is because:

- The pursuit of assets is neutral or less risky than the pursuit of criminals, who usually have power or influence. The pursuit of these assets can be carried out without the knowledge of the owner of the assets, so it is safer to do;

- The pursuit of assets follows the tendency of human nature as being homo economicus. Humans often commit criminal acts on the grounds of seeking material/money profit. By pursuing the proceeds of crime, it is hoped that the motivation to commit crimes will be reduced (PPATK \& DPR RI, 2011).

Starting from the descriptions above, it can be said firmly that the objective or basic idea for the formation of Law Number 8 of 2010 is not intended to punish as many money launderers as possible, but rather to fully recover state losses if the predicate crime is crimes that harm state finances, and return to the rights if the predicate crime is a crime that harms an individual.

In connection with this, Asep N. Mulyana argued that law enforcement practices that not only emphasize the perpetrators of crime (follow the suspect) but also seek to trace and secure funds and assets (follow the money and follow the assets) that are suspected of originating from a crime a form of an economical approach to law, which not only punishes and imprisons the perpetrator but also seeks to recover the financial and economic losses that result from a crime (Mulyana, 2018).

Furthermore, it is stated that the economic approach to law as an implementation of utility philosophy often pays attention to the aspects of the benefits of legal action or process. In this case, the function of law is not only aimed at creating social order and protection of society (social order \& social defense), but also what is no less important is the welfare of society (social welfare). Therefore, law enforcement is not only a form of punishment that processes input and produces output but also pays attention to socio-economic impacts (outcomes) (Mulyana, 2018). 
Analysis of the economic approach in imposing these sanctions is very influential in fulfilling criminal regulation or policy effectiveness. The increase in the crime rate makes law enforcement a major economic activity that costs a lot of money (Nelson, 2020).

Inconsistency of Article 5 paragraph (1) of Law Number 8 of 2010 against the paradigm of the anti-money laundering regime: an economic analysis of the law. As previously stated, the paradigm adopted in the anti-money laundering regime is the follow the money approach. However, when referring to Law Number 8 of 2010, it can be seen that the basic ideas behind the formation of Law Number 8 of 2010 are not fully embodied in some of the substances contained in it. It can be said that there is an inconsistency with the basic idea of the formation of Law Number 8 of 2010.

The basis for the argumentation by the author of this opinion is that in Law Number 8 of 2010 , there are two categories of criminal acts, namely money laundering as regulated in Articles 3, 4, and 5 and other crimes related to regulated money laundering in Articles 11, 12, 14,15 , and 16. The forms of criminal sanctions threatened in these articles are imprisonment, whether formulated singly, namely Article 11 and Article 16, and the threat of sanctions formulated cumulatively between imprisonment and criminal fines in articles $3,4,5,12,14$, and 15 .

Apart from the differences in the formulation system for the threat of sanctions used (singular or cumulative), imprisonment is a sanction put forward in Law Number 8 of 2010. Such a phenomenon is not only found in Law Number 8 of 2010, but has become a trend in existing legislative policies, so it is not an exaggeration that if there is an expression of the types of criminal sanctions, especially in the form of imprisonment, they are still the prima donna sanction.

As it is known, imprisonment is a type of sanction that requires a high cost. As an illustration, the author refers to Choky Ramadhan's research results, where in the results of the study, it is stated that in Indonesia, the state budget originating from public taxes runs out more than five hundred billion rupiahs per year to eat prisoners. These costs are believed to be up to trillions of rupiah if they include calculating the salary of prison wardens and the rehabilitation program's cost. Prison financing is so large that it burdens the people from taxes paid to the state, even though public money in the form of taxes can be used for far more beneficial things such as education, health, and creating an environment free from crime (Ramadhan, 2016). This situation is counterproductive with the basic idea of the formation of Law Number 8 of 2010, which aims to recover as much state loss as possible. What exists is wasting state money.

This phenomenon has received attention at the Fifth United Nations Congress on the Prevention of Crime and the Treatment of Offenders in 1975 in Geneva. The congress report stated:

The past decade witnessed an interest, in different parts of the world, in developing some estimates of the "cost of crime". But there is as yet a dearth of techniques for measuring the impact of crime on-economic and social development. This is a central issue that remains to be scientifically explored. The problem in the poorer countries is made all the more acute by the scarcity of available resources urgently needed to meet the competing demands of development. The indications that crime and crime control consume a significantly greater proportion of these scarce resources in the poorer countries than in the richer ones need to be systematically pursued for their policy and planning implications (United Nations, 1915).

In the congressional report, it was mentioned that the cost of crime control had eroded a large proportion of the existing budget and resources in a country, even for developing countries, the need for budget and resources allocated to tackling crime is greater than in developed countries.

It was further mentioned in the congress report, expenditures on services for crime prevention and control are met by higher taxes on the citizenry and divert limited resources from other pressing needs (United Nations, 1915). Financing for the prevention and overcoming of crime eventually becomes a burden on the people in the form of higher taxes 
and other urgent needs that must be put aside because the existing budget is diverted for prevention and overcoming of crime.

As an illustration of the magnitude of the budget allocation referred to, the congress report stated, official statistics indicate that in at least one developing country, the budget appropriation for internal order exceeds that for education and health combined (United Nations, 1915).

According to Feby Mutiara Nelson, crime causes the direct cost of crime and indirect cost of crime. Indirect losses include costs to the state in preventing and overcoming crimes and costs for law enforcement. The costs required for law enforcement are enormous, starting from the investigation, investigation, prosecution, examination in court to implement court decisions. It can even be added to the cost of education or training of law enforcers, law enforcement facilities and infrastructure, and so on (Nelson, 2020).

So, strictly speaking, efforts to control crime require enormous costs. Even for this purpose, one must divert budgets that should be used for other, no less essential interests.

From the descriptions above, in connection with the form of pro parte dolus pro parte culpa in Article 5 paragraph (1) of Law Number 8 of 2010, which regulates passive money laundering, which allows passive money laundering which is carried out due to negligence is also threatened with imprisonment, an essential point that the writer would like to make is that considering the seriousness of the criminal act of passive money laundering committed due to negligence, it is not appropriate that the form of criminal sanction that is punished is imprisonment. Because it would be counterproductive with the spirit of the formation of Law Number 8 of 2010 itself, which is the objective and also the basic idea for the construction of Law Number 8 of 2010 is to return as much state financial losses as possible, but with the choice of the form of imprisonment sanctions for passive money laundering, which is committed due to negligence, will use up the state budget for minor offenses.

Gustav Radbruch argues that there are three fundamental law values: justice, usefulness, and legal certainty. These three fundamental values are also often referred to as legal objectives. Satjipto Rahardjo, in his work entitled "Ilmu Hukum", tries to compare the three fundamental values of the law with three variables that function as judges of the validity of the law in an equal position. These variables are in the form of philosophical aspects, sociological aspects, and juridical aspects.

The comparison scheme that is made describes the relationship between the law's three fundamental values and the three aspects that assess the law's validity. First, the relationship's specific form is the relationship between justice and philosophical (philosophical) aspects. Second, the relationship between usefulness (usefulness) and sociological aspects, and third, the relationship between legal certainty and juridical aspects (Rahardjo, 1986). However, in this section, the author limits the discussion to the second relationship's emphasis, especially concerning criminal sanctions attached to the passive money laundering crime committed due to negligence.

Talking about the benefits of using law can be seen from the economic side of the law itself. In the context of criminal law, Romli Atmasasmita put forward the essence of this relationship:

The development of economic analysis regarding the special law against criminal law is a new force that can improve the moral of criminal law so that it can be used efficiently and meaningfully for improving the welfare of society. This can happen if criminal law experts seriously pay attention to the advantages and disadvantages of the use of criminal law, which has been seen as an instrument capable of causing a deterrent effect and stopping crimes that occur in society. The new view of the economic analysis approach to criminal law actually changes the paradigm of classical criminal law (right and wrong) to economic-based criminal law, namely how big the social and economic impact of the people from the use of criminal law (Atmasasmita \& Wibowo, 2017).

In efforts to tackle crime using criminal law, the state certainly requires a high cost. This is also a concern in the fifth UN Congress, as previously mentioned, which includes implementing imprisonment's operational costs. In Indonesia, financing for such purposes is 
included in the scope of state expenditure, the source of which is allocated from the state budget.

This is an implementation of Article 11, paragraph 2 of Law Number 17 of 2003 concerning State Finance, which states that the state budget consists of the income budget, expenditure budget, and financing. Meanwhile, paragraph 3 of the law states that state revenue consists of tax revenues, non-tax revenues, and grants. Tax revenue always occupies the top position in contributing to state revenue. So it is appropriate to say that taxes are the backbone of the state budget (Soeriaatmadja et al., 2010). Article 1 point 1 of Law Number 6 of 1983 concerning General Provisions and Tax Procedures defines tax as a mandatory contribution to the state owed by an individual or entity that is compelling under law, without receiving direct compensation and is used for the state needs for the greatest prosperity of the people. From the description above, it can be said that in the end the costs of overcoming crimes, including the operational costs of implementing imprisonment sanctions, are borne by the people in the form of taxes.

Meanwhile, the tax has three functions: a budget function (budgeter), a regulatory function (regularend), and a social function. The function of the budget (budgeter) of taxes is to put as much money into the state treasury as possible for state expenditure needs. The function of regulating (regularend) of taxes means that taxes function to drive society in the means of the economy to improve people's welfare. This regulatory function uses taxes to encourage and control community activities to align with government plans and desires. The social function means the recognized right of private property, and its use must not conflict with the community's interests. In other words, the amount of tax collection must be adjusted to the strength of a person to achieve the highest need satisfaction after deducting (with absolute) primary needs (Negara, 2017).

If you pay attention, the budget (budgeter) function in taxes is basically in line with the concept of following the money in Law Number 8 of 2010, which seeks to increase state revenue. This view is also written in the academic paper of the Draft Law Number 8 of 2010, which states that with consistent enforcement of the law against money laundering, assets resulting from criminal acts will be confiscated by the state so that the state will receive significant additional income for useful activities. Furthermore, it is hoped that with law enforcement to eradicate money laundering, state income from the tax sector will increase. On the other hand, with consistent law enforcement that reduces the crime rate, the microeconomic activity becomes more efficient because criminals' high-cost economy is reduced (PPATK \& DPR RI, 2011). In comparison, the development of an anti-money laundering regime in Australia is also oriented towards increasing state tax revenues so that many tax evasion cases have been uncovered and state income from taxation has increased (PPATK \& DPR RI, 2011).

Strictly speaking, the government's efforts to increase state revenue are carried out through various methods, including through taxes and law enforcement against money laundering, which is oriented towards pursuing the proceeds of crime, then returning it to the state (if the state is injured). Starting from the logic of thinking like this, with the existence of large state budget expenditures, especially for the operationalization of the implementation of imprisonment against passive money laundering carried out due to negligence, the government's efforts to increase state revenue, especially from the tax sector and also efforts to recover state losses through law enforcement against money laundering will be a waste of time. In this connection, Andreas Nathaniel Marbun and Revi Laracaka stated:

The government is the party that has to determine the efforts and costs of law enforcement. Without such mechanisms and calculations, state spending for law enforcement costs through the state budget is unclear. Expenditures through the state budget should be seen as an investment, not just a waste of money. It is likewise budgeting for law enforcement through the state budget. There must be a clear monitoring and evaluation system against the budget that has been issued. Do not let the budget be issued for law enforcement, apart from not having clear benchmarks but also not knowing the results of evaluating the given budgeting impact. Finally, the government does not know the effectiveness of using the state's money (Marbun \& Laracaka, 2019). 
This thought is relevant to that expressed by Romli Atmasasmita:

The criminal law policy that has been implemented for approximately sixty years of independence is no longer a solution to the problems but has created a very serious problem because successful law enforcement still uses only quantitative parameters (output) and does not succeed efficiently and effectively because it has ignored the benefits aspects of the impact of the application of the law (outcome) (Atmasasmita, 2017).

On different occasions, Romli Atmasasmita, together with Kodrat Wibowo, argued that, from the perspective of microeconomic analysis, it is proven that the criminal justice process based on repressive laws is inefficient, both from social, economic, political, and legal aspects as well as state finance (Atmasasmita \& Wibowo, 2017). Suppose state expenditures that are not proportional to the state financial losses saved are used to finance education and public health facilities and infrastructure. In that case, it is certainly very useful to strengthen government steps to achieve people's welfare (Atmasasmita \& Wibowo, 2017).

So, for adherents of an economical approach to law, efficiency is the main principle for assessing whether a rule of law or policy or a court decision can be accepted or rejected. To find out whether a law or policy or court decision is efficient or not, it can be done by comparing the benefits and costs (Rahmadi, 2015).

In line with the above opinion, J. Andenaes as quoted by Muladi and Barda Nawawi Arief mentioned:

If one bases the penal law on the concept of social defence, the task will then be to develop it as rationally as possible. The maximum results must be achieved with the minimum of expense to society and the minimum of suffering for the individual. In this task, one must build upon the results of scientific research into the causes of crime and the effectiveness of the various forms of sanction (Muladi \& Arief, 1998).

From this viewpoint, it shows that a rational policy approach is also closely related to an economic approach in the use of criminal sanctions. The economic approach here is not only intended to consider the costs or burdens borne by society (with the use of criminal law) and the results to be achieved, but also in the sense of considering the effectiveness of the criminal sanctions themselves (Muladi \& Arief, 1998).

When connected with legal objectives, this conception is identical with legal objectives in the form of benefits. Utilization as a legal objective is the essence of the utilitarianism teaching pioneered by Jeremy Bentham. Said by Bentham:

Utility is an abstract term. It expresses the property or tendency of a thing to prevent some evil or to procure some good. Evil is pain, or the cause of pain. Good is pleasure, or the cause of pleasure. That which is conformable to the utility, or the interest of an individual, is what tends to augment the total sum of his happiness. That which is conformable to the utility, or the interest of a community, is what tends to augment the total sum of the happiness of the individuals that compose it (Bentham, 1871).

So, according to Bentham, the point is that expediency is an abstract term. This term expresses the nature or tendency of something to prevent evil or to gain good. Evil is misery or the cause of misery. Kindness is pleasure or causes pleasure. What is in accordance with the benefit or interest of an individual is what tends to increase the amount of happiness. And what is in accordance with society's benefit or interest is what tends to increase the amount of happiness of the individuals who make up that society.

Utilities, according to Bentham, are the principles that approve or reject any action that seems to increase or decrease the happiness of the party whose interests are affected by the action. If the interested party is an individual, the utility principle must be designed to increase his happiness, while if the interested party is the community, the utility principle must be directed towards the happiness of the community. In this utilitarianism, the tool of right and wrong is the greatest happiness of most people, famous for its expression of the greatest happiness for the greatest numbers (Marzuki, 2008). About criminal matters, from the perspective of criminal utilitarianism, it has no justification value if it is imposed to add more suffering or harm to society (Harkrisnowo, 2003).

In his preface given in H.L.A Hart's work entitled "Punishment and Responsibility" John Gardner mentions, "What good comes of criminal punishment? How does it help to make the 
world a better place? Criminal punishment, and more generally the criminal justice system that makes it possible, requires a huge investment of money, time, and energy. It has high costs and many casualties. If the system is to be justified, there must be compensating benefits" (Hart, 2008).

Furthermore, if it is necessary to reconsider what was stated by Bentham regarding the use of criminal sanctions:

The general object which all laws have, or ought to have, in common, is to augment the total happiness of the community; and therefore, in the first place, to exclude, as far as may be, every thing that tends to subtract from that happiness: in other words, to exclude mischief. But all punishment is mischief: all punishment in itself is evil. Upon the principle of utility, if it ought at all to be admitted, it ought only to be admitted in as far as it promises to exclude some greater evil. It is plain, therefore, that in the following cases punishment ought not to be inflicted:

- Where it is groundless: where there is no mischief for it to prevent; the act not being mischievous upon the whole;

- Where it must be inefficacious: where it cannot act so as to prevent the mischief;

- Where it is unprofitable, or too expensive: where the mischief it would produce would be greater than what it prevented;

- Where it is needless: where the mischief may be prevented, or cease of itself, without it: that is, at a cheaper rate.

Concretely, according to Bentham, the use of criminal sanctions must be excluded if there are four things, namely groundless, inefficacious, unprofitable, or too expensive, dan needless (Bentham, 2000).

On a different occasion said by Bentham, the case in which punishment ought not to be inflicted may be reduced to four heads: when punishment would be- $1^{\text {st }}$, misapplied; $2^{\text {nd }}$, inefficacious; $3^{\text {rd }}$, Superfluous; $4^{\text {th }}$, too expensive (Bentham, 1871).

Based on the description above, the common thread that can be drawn is that the follow the money approach in Law Number 8 of 2010 has the same mission as the government's efforts to collect taxes, which aims to increase state revenue. And in the end, the state revenue, as stated in the state budget, is used to fulfill the community's welfare.

According to the author's opinion, with the types of criminal sanctions in the form of imprisonment attached to Article 5 paragraph (1) of Law Number 8 of 2010, especially for passive money laundering committed due to negligence, according to the author's opinion, it will only waste the state budget for unauthorized interests proportional. The state budget which is allocated for this purpose should be used for other interests that the wider community can feel. In fact, according to Bentham, laws that give a lot of happiness to the largest part of society will be considered good laws (Rasjidi \& Rasjidi, 2016).

This is an indirect implication of the formulation of Article 5 paragraph (1) of Law Number 8 of 2010 in the form of a pro parte dolus pro parte culpa form of guilt, the consequences of which are passive money laundering in the form of dolus and passive money laundering in the same form of culpa. -sama is punishable by imprisonment, which is accumulated with a fine. In this case, the criminal act of passive money laundering, which is committed due to negligence, is threatened with imprisonment. For this reason, this idea deserves the attention of legislators, especially in the effort to revise Law Number 8 of 2010 in the future.

So strictly speaking, when viewed from the perspective of an economic approach, pro parte dolus pro parte culpa form of guilt in Article 5 paragraph (1) of Law Number 8 of 2010 which will result in passive money laundering which is carried out due to negligence is also punishable by imprisonment spending the state budget only for minor offenses. In other words, it will only waste the state budget for disproportionate interests. With the existence of a large state budget expenditure, especially for the operationalization of the implementation of imprisonment against passive money laundering, which is carried out due to negligence, the government's efforts to increase state revenue, especially from the tax sector, and also efforts to recover state losses through law enforcement to money laundering will become a hopeless problem. The state budget allocated for this purpose should be used to achieve 
public welfare, for example, for use in health, education, and so on. In short, with the existence of a large state budget expenditure, especially for the operationalization of the implementation of imprisonment against passive money laundering committed due to negligence, it will reduce the state budget that should be used to fulfill the welfare of the community.

\section{REFERENCES}

1. Atmasasmita, R. \& Wibowo, K. (2017). Analisis Ekonomi Mikro Tentang Hukum Pidana Indonesia. Jakarta: Kencana.

2. Atmasasmita, R. (2017). Rekonstruksi Asas Tiada Pidana Tanpa Kesalahan (Geen Straf Zonder Schuld). Jakarta: Gramedia Pustaka Utama.

3. Bentham, J. (1871). Theory of Legislation. London: Trubner \& Co , 60, Paternoster Row

4. Bentham, J. (2000). An Introdution to the Principles of Morals and Legislation. Kitchener: Batoche Books.

5. Harkrisnowo, H. (2003). Rekonstruksi Konsep Pemidanaan: Suatu Gugatan terhadap Proses Legislasi dan Pemidanaan di Indonesia. Jakarta: Fakultas Hukum Universitas Indonesia.

6. Hart, H. (2008). Punishment And Responsibility: Essays In The Philosophy Of Law. New York: Oxford University Press.

7. Husak, D. (2008). Overcriminalization: The Limits of The Criminal Law. New York: Oxford University Press.

8. Kristiana, Y. (2015). Pemberantasan Tindak Pidana Pencucian Uang : Perspektif Hukum Progresif. Yogyakarta: Thafamedia.

9. Marbun, A \& Laracaka, R. (2019). Analisa Ekonomi terhadap Hukum dalam Pemidanaan Partai Politik melalui Pertanggungjawaban Korporasi dalam Perkara Tipikor. Jurnal Antikorupsi Integritas. 5 (1): 127-167.

10. Marzuki, P. (2008). Pengantar IImu Hukum. Jakarta: Kencana Prenada Media Group.

11. Muladi \& Arief, B. (1998). Teori-Teori dan Kebijakan Hukum Pidana. Bandung: Alumni.

12. Mulyana, A. (2018). Pendekatan Ekonomi Dalam Penegakan Hukum Terhadap Kejahatan Korporasi. Jakarta: Grasindo.

13. Negara, T. (2017). Ilmu Hukum Pajak. Malang: Setara Press.

14. Nelson, F. (2020). Plea Bargaining \& Deferred Prosecution Agreement. Jakarta: Sinar Grafika.

15. PPATK \& DPR RI. (2011). Memorie van Toelichting: Pembahasan Rancangan UndangUndang Tentang Pencegahan dan Pemberantasan Tindak Pidana Pencucian Uang Buku Dua. Jakarta: Pusat Pelaporan dan Analisis Transaksi Keuangan.

16. Rahardjo, S. (1986). Ilmu Hukum. Bandung: Alumni.

17. Rahmadi, T. (2015). Hukum Lingkungan di Indonesia. Jakarta: RajaGrafindo Persada.

18. Ramadhan, C. (2016). Pengantar Analisis Ekonomi Dalam Kebijakan Pidana di Indonesia. Jakarta: Institute for Criminal Justice Reform.

19. Rasjidi, L. \& Rasjidi, L.S. (2016). Dasar-Dasar Filsafat dan Teori Hukum. Bandung: Citra Aditya Bakti.

20. Santoso, T. (2020). Hukum Pidana: Suatu Pengantar. Depok: RajaGrafindo Persada.

21. Soeriaatmadja, A, et.al. (2010). Laporan Akhir Kompendium Bidang Hukum Keuangan Negara (Sumber-Sumber Keuangan Negara). Jakarta: Badan Pembinaan Hukum Nasional Kementerian Hukum dan HAM-RI.

22. United Nations. (1915). Fifth United Nations Congress on the Prevention of Crime and the Treatment of Offenders: Economic and Social Consequences of Crime: New Challenges for Research and Planning. Geneva: United Nations.

23. Yusuf, M. (2013). Merampas Aset Koruptor: Solusi Pemberantasan Korupsi di Indonesia. Jakarta: Kompas. 